\title{
SKEMA ALTERNATIF PENYALURAN KREDIT USAHA RAKYAT BAGI PELAKU UMKM DENGAN PERAN PEMERINTAH DAERAH SEBAGAI AVALIS
}

\author{
Oleh : \\ Mahendra Wardhana, S.H, M.Kn \\ Jurusan Hukum Fakultas IImu Sosial dan Hukum
}

\begin{abstract}
ABSTRAK
Salah satu problema klasik bagi pelaku Usaha Mikro, Kecil dan Menengah (UMKM) dalam menjalankan usahanya adalah modal. Pembiayaan atau pemberian modal dalam bentuk kredit yang dilakukan oleh Lembaga Keuangan, dalam hal ini Bank, tentu saja dapat diberikan dengan tetap memperhatikan prinsip kehati-hatian. Bank sebagai lembaga keuangan dalam menjalankan prinsip kehati-hatian tentu saja tetap memerlukan collateral (jaminan) yang merupakan salah satu bagian dalam prinsip 5 C (five C's Principle's), selain character, capital, capacity, condition of economic.

Bagi pelaku UMKM yang sedang merintis usahanya tentu saja persyaratan adanya jaminan untuk mendapatkan modal dirasa sangat memberatkan. Umumnya jaminan yang diminta oleh bank untuk memberikan kredit dapat berupa barang bergerak maupun tidak bergerak, namun dalam hal ini tentu saja tidak semua pelaku UMKM memiliki jaminan yang dipersyaratkan tersebut.

Kesulitan persyaratan tentang jaminan bagi pelaku UMKM dalam mendapatkan modal seharusnya menjadi perhatian bagi Pemerintah Daerah khususnya Dinas Koperasi dan UMKM sebagai instansi yang menaungi dan membina pelaku dan UMKM untuk mengantisipasi kesulitan tersebut. Pemerintah Daerah dalam hal ini dapat menjadi avalis (penjamin) untuk kredit yang diajukan oleh para pelaku UMKM tersebut dengan mengadakan perjanjian kerjasama pembiayaan kredit bagi pelaku UMKM dengan bank-bank yang telah ditunjuk oleh Pemerintah Pusat untuk menyalurkan kredit Usaha Rakyat.
\end{abstract}

Kata kunci : Modal, Avalis, Perjanjian Kredit, UMKM

\section{Abstract}

One of the classic problems for perpetrators of Micro, Small and Medium Enterprises (SMEs) in running the business is capital. The provision of financing or capital in the form of loans made by financial institutions, in this case the bank, of course, can be given with due regard to the precautionary principle. Banks as financial institutions in implementing the precautionary principle of course, still require collateral (collateral), which is one part of the principle of C 5 (five C's Principle's), in addition to character, capital, capacity, condition of economic.

For SMEs who are pioneering efforts of course requirement for collateral to obtain capital is considered very burdensome. Generally, collateral demanded by banks to provide credit may be movable or immovable goods, but in this case of course not all SMEs have the collateral required. 
Difficulty terms of guarantee for SMEs in obtaining capital should be a concern of the local government, especially the Department of Cooperatives and SMEs as the institution that houses and foster actors and SMEs to anticipate these difficulties. Local Government in this case can be avalist (guarantor) for credit proposed by the perpetrators of the SME financing entered into an agreement with a credit for SMEs by banks who have been appointed by the Central Government for the People's Business loan portfolio.

Keywords : Capital, AVALIS, the Credit Agreement, SMEs 


\section{PENDAHULUAN}

Dengan diberlakukannya Masyarakat Ekonomi Asean (MEA) pada akhir tahun 2015, negara anggota ASEAN akan mengalami aliran bebas barang, jasa, investasi, dan tenaga kerja terdidik dari dan ke masing-masing negara.Bagi para pelaku Usaha Mikro, Kecil dan Menengah (UMKM) Indonesia, berlakunya MEA seharusnya bukanlah sesuatu yang harus ditakuti. Sebaliknya, MEA harus disikapi secara positif karena membawa peluang yang besar bagi UMKM untuk meraih potensi pasar dan peluang investasi. Untuk memanfaatkan peluang tersebut, UMKM perlu terus berbenah diri guna menghadapi perilaku pasar yang semakin terbuka, khususnya dengan menggali dan mengembangkan kreatifitas dan inovasi. Peran UMKM menjadi sangat penting sebagai pendorong utama penciptaan lapangan pekerjaan dan pertumbuhan ekonomi, baik pada tataran nasional maupun regional, dimana salah satu kelebihan UMKM adalah daya tahannya dalam menghadapi kondisi krisis.

Berdasarkan alinea 3 dan 4 bagian Umum penjelasan atas Undang-Undang Nomor 20 Tahun 2008 tentang Usaha, Mikro, Kecil dan Menengah bahwa Usaha Mikro, Kecil, dan Menengah merupakan kegiatan usaha yangmampu memperluas lapangan kerja dan memberikan pelayanan ekonomisecara luas kepada masyarakat, dan dapat berperan dalam prosespemerataan dan peningkatan pendapatan masyarakat, mendorong pertumbuhan ekonomi, dan berperan dalam mewujudkan stabilitas nasional. Selain itu, Usaha Mikro, Kecil, dan Menengah adalah salah satu pilar utama ekonomi nasional yang harus memperoleh kesempatan utama,dukungan, perlindungan dan pengembangan seluas-luasnya 
sebagai wujud keberpihakan yang tegas kepada kelompok usaha ekonomi rakyat, tanpa mengabaikan peranan Usaha Besar dan Badan Usaha Milik Negara. Meskipun Usaha Mikro, Kecil, dan Menengah telah menunjukkan peranannya dalam perekonomian nasional, namun masih menghadapi berbagai hambatan dan kendala, baik yang bersifat internal maupun eksternal, dalam hal produksi dan pengolahan, pemasaran, sumber dayamanusia, desain dan teknologi, permodalan, serta iklim usaha. ( Riant Nugroho; $2015: 47$ )

Salah satu problema klasik bagi pelaku Usaha Mikro, Kecil dan Menengah (UMKM) dalam menjalankan usahanya adalah modal usaha. Kebutuhan modal sangat terasa pada saat seseorang ingin memulai usaha baru. Pada usaha yang sudah berjalan, modal usaha tetap menjadi kendala lanjutan untuk berkembang. Masalah yang menghadang usaha kecil menyangkut kemampuan akses pembiayaan, akses pasar dan pemasaran, tata kelola manajemen usaha kecil serta akses informasi.Kesulitan usaha kecil mengakses sumber-sumber modal karena keterbatasan informasi dan kemampuan menembus sumber modal tersebut. Padahal pilihan sumber modal sangat banyak dan beragam.

Peran pemerintah daerah dalam pemenuhan kebutuhan modal bagi pelaku UMKM tentu saja tidak hanya terbatas sebagai pihak yang menyediakan informasi belaka kepada pelaku UMKM. Pemerintah Daerah seyogyanya memberikan dukungan yang lebih nyata akan keterbatasan pelaku UMKM dalam hal modal usaha, termasuk namun tidak terbatas pada kebutuhan jaminan sebagai salah satu syarat utama yang dibutuhkan dalam mendapatkan modal tersebut. 
Berdasarkan latar belakang tersebut diatas dengan ini penulis membuat rumusan masalah sebagai berikut :

Bagaimana skema alternatif penyaluran kredit usaha rakyat bagi pelaku Usaha Mikro, Kecil dan Menengah (UMKM) dengan peran pemerintah daerah sebagai avalis?

\section{PEMBAHASAN}

Pembiayaan atau pemberian modal dalam bentuk kredit yang dilakukan oleh Lembaga Keuangan, dalam hal ini Bank, tentu saja dapat diberikan dengan tetap memperhatikan prinsip kehati-hatian.Secara umum dapat dikatakan bahwa tugas pokok perbankan di Indonesia adalah membantu pemerintah dalam mengatur, menjaga dan memelihara kestabilan nilai rupiah,mendorong kelancaran produksi dan pembangunan serta memperluas kesempatan kerja guna meningkatkan taraf hidup rakyat.(M. Manullang; $2013: 110)$

Kredit berasal dari bahasa Romawi "credere" yang berarti percaya. Dasar dari kredit adalah adanya kepercayaan. Pihak yang memberikan kredit (kreditur) percaya bahwa penerima kredit (debitur) akan sanggup memenuhi segala sesuatu yang telah diperjanjikan, baik menyangkut jangka waktunya, maupun prestasi dan kontraprestasinya. Kondisi dasar seperti ini diperlukan oleh Bank, karena dana yang ada di bank sebagian besar milik pihak ketiga, untuk itu diperlukan kebijaksanaan oleh Bank dalam penggunaan dana tersebut termasuk di dalamnya untuk menentukan pemberian kredit. (Muhammad Djumhana; 1993 : 217) 
Bank sebagai lembaga keuangan dalam menjalankan prinsip kehati-hatian menerapkan formula 5 C (five C's Principle's) yang merupakan formula yang dipegang teguh oleh bank dalam menganalisa permohonan kredit untuk kemudian menyalurkan kreditnya. Mengenai formula $5 \mathrm{C}$ bisa diuraikan sebagai berikut : (Hermansyah; 2012 : 64-65)

\section{Character}

Bahwa calon nasabah debitur memiliki watak, moral dan sifat-sifat pribadi yang baik. Penilaian terhadap karakter ini dilakukan untuk mengetahui tingkat kejujuran, integritas dan kemauan dari calon nasabah debitur untuk memenuhi kewajiban dan menjalankan usahanya. Informasi ini dapat diperoleh oleh bank melalui riwayat hidup, riwayat usaha, dan informasi dari usaha-usaha yang sejenis.

\section{Capacity}

Yang dimaksud dengan capacity dalam hal ini adalah kemampuan calon nasabah debitur untuk mengelola kegiatan usahanya dan mampu melihat prospektif masa depan, sehingga usahanya akan dapat berjalan dengan baik dan memberikan keuntungan yang menjamin bahwa ia mampu melunasi utang kreditnya dalam jumlah dan jangka waktu yang telah ditentukan.

\section{Capital}

Dalam hal ini bank harus terlebih dahulu melakukan penelitian terhadap modal yang dimiliki oleh pemohon kredit. Penyelidikan tidaklah semata-mata didasarkan pada besar kecilnya modal, akan tetapi lebih difokuskan kepada 
bagaimana distribusi modal ditempatkan oleh pengusaha tersebut, sehingga segala sumber yang telah ada dapat berjalan secara efektif.

\section{Collateral}

Adalah jaminan untuk pesertujuan pemberian kredit yang merupakan sarana pengaman (backup) atas resiko yang mungkin terjadi atas wanprestasinya nasabah debitur dikemudian hari, misalnya terjadi kredit macet. Jaminan ini diharapkan mampu melunasi sisa utang kredit baik utang pokok maupun bunganya.

\section{Condition of Economy.}

Dalam pemberian kredit oleh bank, kondisi ekonomi secara umum dan kondisi sector usaha pemohon kredit perlu memperoleh perhatian dari bank untuk memperkecil resiko yang mungkin terjadi yang diakibatkan oleh kondisi ekonomi tersebut.

Dalam menyalurkan kredit Bank sebagai lembaga keuangan dalam menjalankan prinsip kehati-hatian tentu saja tetap memerlukan collateral (jaminan) yang merupakan salah satu bagian dalam prinsip $5 \mathrm{C}$, selain character, capital, capacity, condition of economic.Bagi pelaku UMKM yang sedang merintis usahanya tentu saja persyaratan adanya jaminan untuk mendapatkan modal dirasa sangat memberatkan. Umumnya jaminan yang diminta oleh bank untuk memberikan kredit dapat berupa barang bergerak maupun tidak bergerak, namun dalam hal ini tentu saja tidak semua pelaku UMKM memiliki jaminan yang dipersyaratkan tersebut.

Secara garis besar hukum jaminan dilihat dari sumbernya bisa dibedakan menjadi hukum jaminan secara umum yang bersumber dari Undang-undang dan 
Hukum Jaminan secara khusus lahir berdasarkan Perjanjian. Privilege adalah hak jaminan yang lahir karena undang-undang, sedangkan gadai dan hipotik, hak tanggungan serta fidusia lahir karena diperjanjikan antara debitur dan kreditur. (Darmawan Tri Budi Utomo, Sri Mulyani, Agnes Maria Janni; 2006 : 16)

Pemberian jaminan dalam perjanjian kredit diharuskan dalam dunia perbankan konvensional karena pada dasarnya, sumber dana yang disalurkan berasal dari masyarakat atau tabungan masyarakat. Dengan demikian, dana kredit yang disalurkan harus dilakukan secara hati-hati (prudent). Meskipun Kredit Tanpa Agunan (KTA), Kredit Usaha Rakyat (KUR), atau kredit mikro lainnya yang diberikan kepada debitur tanpa adanya syarat agunan, pemberian kredit jenis tersebut dilakukan sangat selektif. Biasanya dilakukan dengan limit (batas) yang tidak terlalu besar atau hanya khusus ditujukan untuk menolong masyarakat ekonomi lemah. (Irma Devita Purnamasari; $2011:$ 18)

Berdasarkan Peraturan Menteri Koordinator Bidang Perekonomian Republik Indonesia selaku Ketua Komite Kebijakan Pembiayan Bagi Usaha Mikro, Kecil dan Menengah Nomor 8 tahun 2015 tentang Pedoman Pelaksanaan Kredit Usaha Rakyat (selanjutnya disebut Pedoman KUR), khususnya dalam Pasal 1 angka 1 bahwa Kredit Usaha Rakyat yang selanjutnya disingkat KUR adalah kredit/ pembiayaan modal kerja dan atau investasi kepada debitur usaha yang produktif dan layak namun belum memiliki agunan tambahan atau agunan tambahan belum cukup. Sedangkan penyalur KUR adalah bank atau lembaga keuangan bukan bank yang ditunjuk untuk menyalurkan KUR. 
Pasal 3 Pedoman KUR menyebutkan bahwa Pelaksanaan KUR bertujuan untuk:
a. meningkatkan dan memperluas penyaluran KUR kepada usaha produktif;
b. meningkatkan kapasitas daya saing usaha mikro, kecil, dan menengah; dan
c. mendorong pertumbuhan ekonomi dan penyerapan tenaga kerja.

KUR sebagai skema kredit atau pembiayaan modal kerja dan atau investasi yang khusus diperuntukkan bagi Usaha Mikro Kecil Menengah dan Koperasi (UMKMK) di bidang usaha produktif dan layak (feasible), namun mempunyai keterbatasan dalam pemenuhan persyaratan yang ditetapkan Perbankan (belum bankable). Belum Bankabledalam hal ini dapat diartikan bahwa UMKM yang belum dapat memenuhi persyaratanperkreditan pembiayaan dari Bank, seperti dalam penyediaan agunan.

Pengaturan jaminan dalam suatu perjanjian kredit bank konvensional selalu ditempatkan dalam pasal khusus. Jaminan biasanya ditetapkan dengan mengutamakan kekuatan eksekusi paling tinggi, yaitu yang berbentuk fixed asset (dalam hal ini rumah dan atau tanah) dan dapat dibebani Hak Tanggungan. Alasannya, baru Hak Tanggungan saja yang punya "aturan main" sangat jelas dengan prosedur eksekusi lebih mudah, diantara berbagai jenis jaminan yang ada dan diterapkan di Indonesia. Adapun pengikatan jaminan dalam suatu pemberian kredit biasanya dilakukan secara terpisah dari perjanjian kredit yang dilakukan dan dibuat dalam bentuk Akta Notaris (khususnya untuk fidusia, cessie, gadai, hipotek kapal, SKMHT, dan berbagai jenis akta jaminan lainnya) atau SKTA Pejabat 
Pembuat Akta Tanah (khusus untuk SKMHT dan APHT (Irma Devita Purnamasari : $2011 ; 22-23)$

Dalam praktik perbankan dikenal berbagai bentuk alternatif yang digunakan sebagai pengganti jaminan. Walaupun tidak punya kekuatan seperti semantap jaminan yang sudah diatur dalam aturan dan lembaga jaminan yang pasti (sebagaimana halnya dengan Hak Tanggungan, Fidusia, Hipotek, Gadai maupun Personal/Company Guarantee).(Irma Devita Purnamasari; 2011 : 161)

Adanya Undang-Undang Nomor 1 tahun 2016 tentang Penjaminan (selanjutnya disebut Undang-Undang Penjaminan) memang diharapkan menunjang kebijakan pemerintah, terutama dalam rangka mendorong kemandirian usaha dan pemberdayaan dunia usaha, khususnya usaha mikro, kecil, dan menengah serta koperasi dalam perekonomian nasional serta meningkatkan akses bagi dunia usaha, khususnya usaha mikro, kecil, dan menengah serta koperasi dan usaha prospektif lainnya kepada sumber pembiayaan. Hal tersebut sesuai dengan Pasal 3 UndangUndang Penjaminan tentang tujuan Usaha Penjaminan.

Pelaku UMKM tentu saja tidak boleh berharap terlalu besar tentang adanya Undang-Undang Penjaminan ini. Hal ini tampak dari Badan hukum Lembaga Penjamin yang menurut Pasal 7 UU Penjaminan harus berbentuk perusahaan umum, perseroan terbatas atau koperasi, yang ketiganya merupakan badan hukum yang tentu saja bertujuan mencari keuntungan. Disamping itu berdasarkan Pasal 43 UU Penjaminan sendiri telah ditentukan tentang adanya timbal Jasa, dimana dalam Pasal tersebut disampaikan bahwa dalam melaksanakan kegiatan usahanya, Perusahaan Penjaminan menerima Imbal Jasa Penjaminan (IJP), yang merupakan 
sejumlah uang yang diterima oleh Perusahaan Penjaminan dari Terjamin dalam rangka kegiatan Penjaminan.

Bantuan dari pemerintah tentang kesulitan jaminan ini dirasa masih "tanggung", pemerintah masih setengah-setengah dalam membantu UMKM. Menunjuk pada Pasal 9 ayat 2 dan 3 Pedoman KUR bahwa Imbal jasa penjaminan bagi perusahaan penjamin berdasarkan hasil kesepakatan dengan Penyalur KUR.Imbal jasa penjaminan sebagaimana dimaksud pada ayat (2) menjadi bagian komponen dalam subsidi bunga. Hal ini bisa disimpulkan bahwa bunga bank akan lebih kecil seandainya bagian dari Imbal Jasa tersebut tidak menjadi komponen subsidi bunga.

Berdasarkan Pasal 13 Pedoman KUR, bahwa penyaluran KUR Mikro diberikan kepada penerima KUR dengan jumlah palingbanyak sebesar Rp25.000.000 (dua puluh lima juta rupiah), dengan suku bunga KUR Mikro sebesar $12 \%$ (dua belasperseratus) efektif pertahun atau disesuaikan dengan suku bunga flat yang setara, dengan jangka waktu KUR Mikro paling lama 3 (tiga) tahun untuk kredit/pembiayaan modal kerja. Sedangkan menurut Pasal 10 Pedoman KUR agunan pokok agunan pokok KUR adalah usaha atauobyek yangdibiayai oleh KUR, namun dalam praktek dimana bank penyalur KUR tetap meminta jaminan tambahan kepada penerima KUR (debitur).

Pasal 10 Pedoman KUR tersebut sesuai dengan ketentuan Pasal 1131 KUH Perdata yang menyatakan diletakkannya asas umum hak seorang kreditur terhadap debiturnya. Pasal 1131 KUHPerdata tersebut berbunyi "Segala kebendaan si berhutang, baik yang bergerak maupun tidak bergerak, baik yang sudah ada 
maupun yang baru akan ada di kemudian hari, menjadi tanggungan untuk segala perikatan perseorangan."

Jadi hak-hak tagihan seorang kreditur dijamin dengan :

a. Semua barang debitur yang sudah ada, artinya yang sudah ada pada saat hutang dibuat.

b. Semua barang yang akan ada berarti barang-barang yang pada saat pembuatan hutang belum menjadi kepunyaan debitur tetapi kemudian menjadi miliknya. Dengan perkataan lain, hak kreditur meliputi barang-barang yang akan menjadi milik debitur, asal kemudian benar-benar menjadi miliknya.

c. Barang bergerak maupun barang tidak bergerak.

Ketiga poin di atas menunjukkan, bahwa piutang kreditur menindih pada seluruh harta debitur tanpa kecuali.

Kesulitan persyaratan tentang jaminan bagi pelaku UMKM terutama dalam KUR Mikro dalam mendapatkan modal seharusnya menjadi perhatian bagi Pemerintah Daerah khususnya Dinas Koperasi dan UMKM sebagai instansi yang menaungi dan membina pelaku dan UMKM untuk mengantisipasi kesulitan tersebut. Pemerintah Daerah dalam hal ini dapat menjadi avalis (penjamin) untuk kredit yang diajukan oleh para pelaku UMKM tersebut dengan mengadakan perjanjian kerjasama pembiayaan kredit bagi pelaku UMKM dengan bank-bank yang telah ditunjuk oleh Pemerintah Pusat untuk menyalurkan KUR.

Avalis atau penanggungan lazim dikenal dalam kontrak kerja sama atau perjanjian timbal balik, terlebih khusus lagi dalam perjanjian perkreditan yang mana pihak kreditur acap kali membutuhkan jaminan tambahan (selain jaminan 
kebendaan) atas utang debiturnya.Dasar hukum dari avalis atau penanggung adalah Pasal 1820 Kitab Undang-Undang Hukum Perdata yang berbunyi "Penanggungan ialah persetujuan dimana pihak ketiga demi kepentingan kreditur, mengikatkan diri untuk memenuhi perikatan debitur, bila debitur itu tidak memenuhi perikatannya".

Ada tiga hal yang meliputi unsur penanggungan utang, yaitu:

1. Penanggungan utang diberikan untuk kepentingan kreditur.

2. Utang yang ditanggung merupakan suatu kewajiban prestasi atau perikatan yang sah demi hukum.

3. Kewajiban penanggung untuk memenuhi atau melaksanakan kewajiban debitur baru ada setelah debitur wanprestasi.

Skema alternatif yang dapat dilakukan oleh Pemerintah Daerah khususnya Dinas Koperasi dan UMKM dapat digambarkan sebagai berikut :

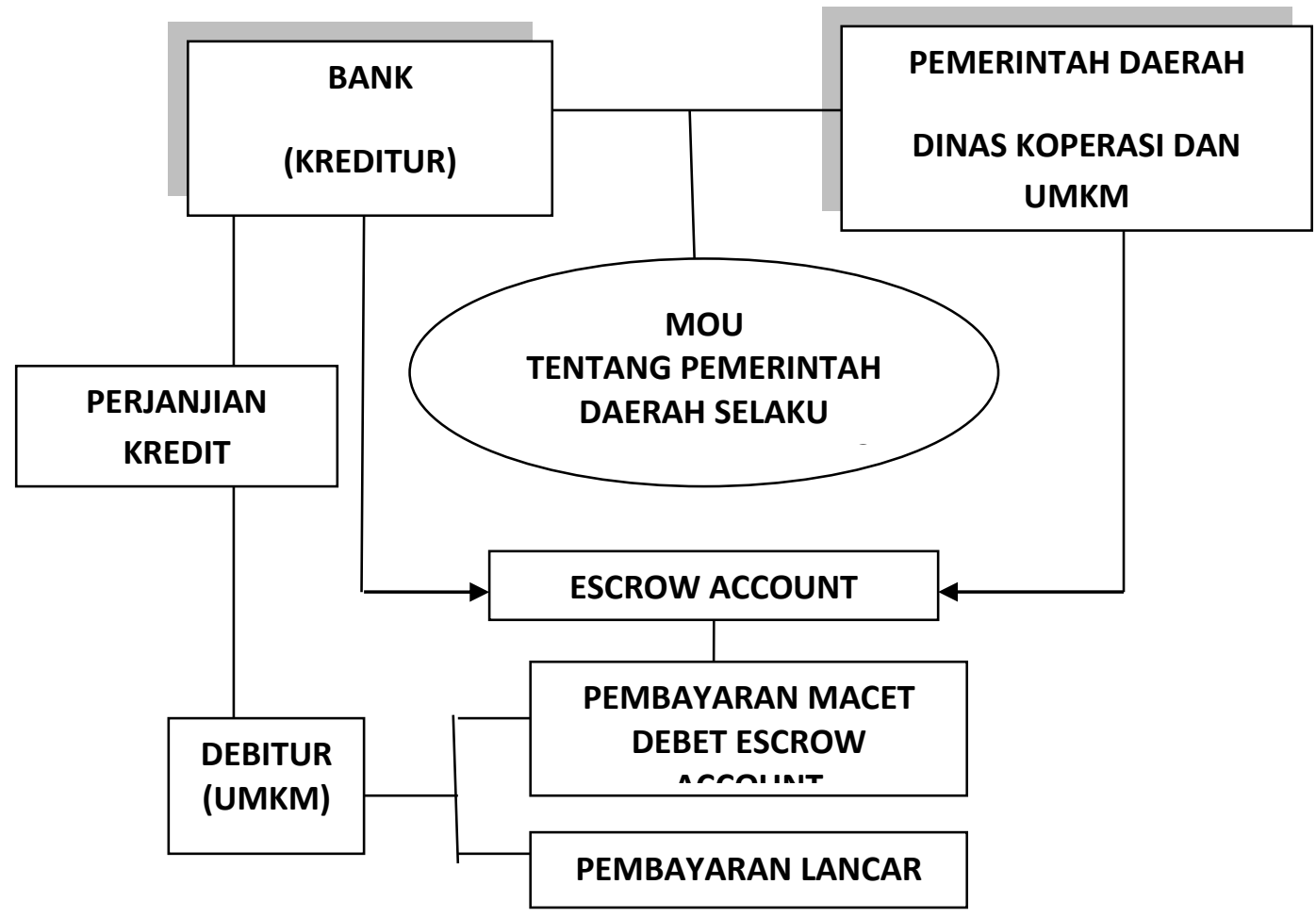


Skema alternatif tersebut dapat dijelaskan melalui mekanisme sebagai berikut :

1. Pemerintah Daerah membentuk tempat-tempat yang akan dipergunakan untuk melakukan pemasaran bagi produk-produk UMKM seperti halnya sentra UMKM, Dewan Kesenian Rakyat Daerah (Dekranasda), dimana selain modal, tempat (lokasi) usaha juga menjadi permasalahan pokok seorang pelaku UMKM yang ingin memasarkan produknya.

2. Kedudukan Pemerintah Daerah khususnya Dinas Koperasi dan UMKM sebagai avalis dapat dilakukan dengan diawali suatu perjanjian kerjasama penjaminan bank yang ditunjuk dengan bank yang menyalurkan KUR. Dalam kedudukannya sebagai avalis tentu saja Pemerintah Daerah khususnya Dinas Koperasi dan UMKM harus memiliki dana yang akan ditaruh di dalam escrow account (rekening penampungan yang dibuka atas dasar kesepakatan para pihak khusus untuk tujuan tertentu) pada bank tersebut. Dana dalam escrow account akan didebet seandainya pelaku UMKM tidak dapat membayar angsuran.

3. Hal tersebut dapat dilakukan seandainya Pemerintah Daerah khususnya Dinas Koperasi dan UMKM memiliki akses untuk menyimpan dana tersebut. Caranya adalah dengan membuka sentra UMKM sebagaimana dimaksud dalam poin 1, dimana nantinya dari setiap penjualan barang milik UMKM akan ada pembagian keuntungan antara Pemerintah Daerah dengan pelaku UMKM, misalnya 70\%: 30\%. $30 \%$ bagian tersebut masuk dalam escrow account, yang akan diblokir sebagai avalis. Dana dalam Escrow Account akan tetap terjaga sebesar 30\% dan akan didebet seandainya terjadi wanprestasi dalam pembayaran oleh debitur, dalam hal ini adalah UMKM. 
4. Satu bulan sejak tanggal pencairan kredit tersebut maka debitur (UMKM) berkewajiban untuk melakukan pembayaran angsuran secara bulanan ke rekening atas nama masing debitur. Selama Kredit belum lunas dan apabila kewajiban angsuran pinjaman tidak dibayar oleh debitur maka bank berhak untuk mendebet rekening yang ada di dalam Escrow Account sebesar kewajiban kredit yang belum dibayar, ditambah dengan denda yang berlaku di dalam perjanjian kredit.

\section{KESIMPULAN}

Berdasarkan pembahasan tersebut diatas dapat kami simpulkan beberapa hal sebagai berikut :

1. Kesulitan persyaratan tentang jaminan bagi pelaku UMKM terutama dalam KUR Mikro dalam mendapatkan modal seharusnya menjadi perhatian bagi Pemerintah Daerah dengan menjadi avalis (penjamin) untuk kredit yang diajukan oleh para pelaku UMKM tersebut dengan mengadakan perjanjian kerjasama pembiayaan kredit bagi pelaku UMKM dengan bank-bank yang telah ditunjuk oleh Pemerintah Pusat untuk menyalurkan KUR.

2. Dalam kedudukannya sebagai avalis tentu saja Pemerintah Daerah khususnya Dinas Koperasi dan UMKM harus memiliki dana yang akan ditaruh di dalam escrow account (rekening penampungan yang dibuka atas dasar kesepakatan Para Pihak khusus untuk tujuan tertentu) pada bank tersebut. Dana dalam Escrow Account akan tetap terjaga akan didebet seandainya terjadi wan prestasi dalam pembayaran oleh debitur, dalam hal ini adalah UMKM. 
Berdasarkan kesimpulan tersebut diatas, kami memberikan saran sebagai berikut :

1. Pemerintah Daerah khususnya Dinas Koperasi dan UMKM dapat bertindak selaku avalis dengan menandatangani suatu perjanjian kerjasama penjaminan dengan bank yang menyalurkan KUR. Pemerintah Daerah membentuk tempattempat yang akan dipergunakan untuk melakukan pemasaran bagi produkproduk UMKM seperti halnya sentra UMKM, Dewan Kesenian Rakyat Daerah (Dekranasda), dimana selain modal, tempat (lokasi) usaha juga menjadi permasalahan pokok seorang pelaku UMKM yang ingin memasarkan produknya.

2. Sebagai avalis, maka setiap penjualan barang milik UMKM akan ada pembagian keuntungan antara Pemerintah Daerah dengan pelaku UMKM, misalnya 70\%: 30\%. $30 \%$ bagian tersebut masuk dalam escrow account, yang akan diblokir sebagai avalis. Dana dalam Escrow Account akan tetap terjaga sebesar 30\%dan akan didebet seandainya terjadi wan prestasi dalam pembayaran oleh debitur, dalam hal ini adalah UMKM.Selama Kredit belum lunas dan apabila kewajiban angsuran pinjaman tidak dibayar oleh debitur maka bank berhak untuk mendebet rekening yang ada di dalam Escrow Account sebesar kewajiban kredit yang belum dibayar, ditambah dengan denda yang berlaku di dalam Perjanjian Kredit. 


\section{DAFTAR PUSTAKA}

Darmawan Tri Budi Utomo, Sri Mulyani, Agnes Maria Janni, 2006, Hukum Jaminan di Indonesia (diatur dalam Buku II KUHPerdata dan diluar KUHPerdata), Badan Penerbit Universitas Diponegoro Semarang, Semarang.

Hermansyah, 2012, Hukum Perbankan Nasional Indonesia, Kencana prenada media group, Jakarta.

Irma Devita Purnamasari, 2011, Hukum Jaminan Perbankan, Kaifa, Bandung.

J. Satrio, 2002, Hukum Jaminan Kebendaan, hal 4, PT. Citra Aditya Bakti, Bandung.

M. Manullang, 2013, Pengantar Bisnis, PT. Indeks, Jakarta.

Muhammad Djumhana, 1990, Hukum Perbankan di Indonesia, Citra Aditya Bakti, Bandung.

Riant Nugroho, 2015, Membangun Entrepreneur Indonesia (Tantangan Manajemen Pemerintahan Jokowi), Elex Media Computindo, Jakarta.

\section{PERATURAN PERUNDANG-UNDANGAN :}

Kitab Undang-Undang Hukum Perdata.

Undang-Undang Nomor 20 Tahun 2008 tentang Usaha, Mikro, Kecil dan Menengah.

Undang-Undang Nomor 1 tahun 2016 tentang Penjaminan.

Peraturan Menteri Koordinator Bidang Perekonomian Republik Indonesia selaku Ketua

Komite Kebijakan Pembiayan Bagi Usaha Mikro, Kecil dan Menengah Nomor 8 tahun 2015 tentang Pedoman Pelaksanaan Kredit Usaha Rakyat. 